\title{
Of persons and organisms: a reply to Howsepian
}

\author{
Michael Lockwood University of Oxford, Oxford
}

\begin{abstract}
Howsepian has presented a number of thought experiments, which are designed to undermine my claim that our identity through time is grounded in the continued existence of those structures in our brains which directly underlie mental functioning. I argue that the conclusions which Howsepian draws from these thought experiments are mistaken, and that his discussion of them is vitiated, in particular, by his failure to distinguish between personal identity and the identity of the associated human organism.
\end{abstract}

My disagreement with Howsepian is really twofold. First, we disagree about the identity conditions (over time and across possible worlds) of living human organisms. Secondly, we disagree about what ontological category he and I, as a matter of metaphysical necessity, belong to. Specifically Howsepian thinks that we are both of us essentially living human organisms, whereas I do not. I wish to make a distinction between a living human organism and the associated person, and would insist that what I essentially am - what I am at all times and in all possible worlds in which I exist at all - is not a living human organism, but a person. (This is very much in the spirit of John Locke's celebrated distinction between man and person, in his Essay Concerning Human Understanding (1690), II.xxvii.8-9. But my own use of the term "person" is here intended to follow common sense, rather than Locke's own usage. ${ }^{1}$ )

The availability of this distinction between human organisms and persons allows me to hold that the living human organism associated with the person that is me came into existence before I did. As a philosophical materialist (though one who is deeply perplexed by consciousness), I regard my existence as having begun with the coming into existence of those brain structures which are directly involved in my mental processes, especially conscious ones, and as being due to end with the eventual destruction of those structures. ${ }^{2}$ Moreover, a brain which had consisted, from the outset, of wholly different cells, albeit

\section{Key words}

Embryo; personal identity; twinning. the progeny of the same fertilised ovum, would, in my view, have been a different brain (however qualita- $\mathbb{D}$ tively similar to my actual one); and the person tow which it would have given rise would accordingly not $-\vec{A}$ have been me. This alone is sufficient reason for $m e$ to $\overrightarrow{0}$ answer "No" to the question: "would you have을 existed if the cells whose progeny in fact gave rise to your brain had given rise to your liver instead, and $\mathbf{D}_{\mathbb{D}}$ vice versa?" But, as I see it, the answer "No" should은 have considerable plausibility, even for those who think that they are essentially living human organisms. For if the identity of the organs is completely $\vec{\theta}$ different, doesn't it follow that the identity of the. organism is likewise different? Neverthele Howsepian wishes to answer "Yes" to my questiळ̄; and in defence of this answer, bids us consider thought experiment, in which the cells in my brain are gradually replaced by functionally identical cells $\frac{2}{\varrho}$ derived from totipotent cells in the sinusoids of my liver.

I share Howsepian's intuition regarding this example, that it would still be me. But I don't see this as in the least undermining my original claim Consider the famous "Ship of Theseus", which in the course of time has all of its planks and fittings:gradually replaced. The fact that we here have con- - . tinuity - and continuing functionality - throughoutô the envisaged change, makes it at least a defensible $₹$ position that what exists at the end of this process is the same ship. But no one would think that we should have had the same ship had there been, at the을. construction stage, a completely different set of planks. By analogy, it is surely sufficient, for my con- tinued identity over time, that there is a continuity within that physiological structure which underlies $\tilde{\omega}^{-}$ mental functioning; and such continuity is clearlyo consistent with a gradual turnover of cells. (Indeed ${ }_{0}$ I see no good reason to deny that what we have, at the end of the process, is the same brain; after all, in? respect of other organs, a turnover of cells is the norm.) But that is not to say that I should still have? existed if, to begin with, there had been a completely different set of brain cells.

Interestingly, Howsepian goes on to consider ao variant of this thought experiment, in which the original brain cells die, and are replaced by new ones, 
but at the cost of replacing the original structure with a very different one. Presumably, the replacement causes all the original memories to be destroyed; and although extensive retraining can restore functionality, the resultant individual resembles the original one psychologically no more than would an identical twin brought up independently. Still, Howsepian argues that what results is the same human organism as that which possessed the old brain. But if so, doesn't this make my point? Such a situation simply cries out for the distinction between human organisms and persons. In the variant example, we have the same organism, perhaps. But the same person? Surely not.

The same distinction may be brought into play in response to another of Howsepian's thought experiments. This is designed to cast doubt on my conception of when a person ceases to exist: namely, that it occurs when those brain structures which are directly involved in mental (and more specifically, conscious) processes are destroyed. Howsepian imagines a process of neural regeneration to occur, subsequent to such destruction, with the consequence that replacement structures come into being, and the capacity for consciousness is accordingly restored. Once again, I wouldn't quarrel with Howsepian's claim that we then have the same living organism. (Not because I'm totally convinced that this is the correct thing to say, but because, given my views, nothing of deep philosophical significance hinges on the answer.) But I would insist that the person associated with the regenerated brain is a newly created person: one who comes into existence only in the course of the envisaged regeneration.

Even though I don't share their view, I still see no reason why those who follow Howsepian in thinking that the likes of you and me are essentially living human organisms, should regard themselves as having come into existence at conception. The true genesis of the organism, I would argue, gets under way not with conception, but with differentiation: the word "organism", it seems to me, is here to be regarded as cognate to "organisation". That what we have, prior to the start of differentiation, is more properly regarded as the raw material out of which one or more organisms are to be constructed is borne out, it seems to me, not only by the phenomenon of twinning, but also by the occasional fusion of zygotes to create a so-called dispermic chimaera $^{3}$ : a single human organism composed of cells of two distinct genetic types. It is reflections such as these which give point to my house analogy. To be sure, there are also striking disanalogies here: for example, bricks and mortar can neither reproduce nor engage in the kind of self-assembly of which embryonic cells are capable. But I cannot see that this invalidates the analogy, given the limited use to which I put it.

Having said that, however, one of the arguments that I used in the article which Howsepian is attacking does now seem to me open to objection. What I did, in effect, was appeal to the transitivity of identity to argue that, where twinning occurs, neither twin can be regarded as numerically identical to the embryo whose division gives rise to the twins, since the twins are plainly not numerically identical with each other. But Derek Parfit ${ }^{4}$ has introduced the very useful notion of survival, which is like identity, except that it does not require transitivity. Work on commissurotomy subjects, ones in whom the corpus callosum has been severed (as a last ditch attempt to limit the damage done by epileptic seizures), has elicited some strikingly dissociated behaviour - to such an extent, indeed, that some (notably Sperry ${ }^{5}$ ) have concluded that the result of the operation, in my terms, is to turn one person (or conscious subject) into two, sharing the same body. It seems to me to be an open question whether this interpretation is correct. ${ }^{6}$ But in any event, were I to accept this interpretation, and were I about to have such an operation performed on my own brain, I could quite properly regard myself as being due to survive the operation, albeit as two people rather than one. I should then have, in prospect, self-interested reasons for caring about the subsequent welfare of the selves associated with both cortical hemispheres. So someone who thinks that what they essentially are comes into existence at conception could take a similar view of twinning: that the original being survives in the two twins, and that regardless of the possibility of twinning, there exists at conception something that has a moral stake in the welfare of all the multiplets that it might turn into. This very point was made in an article which appeared over ten years ago; and the relevant passage concludes with the words:

"So divisibility is, I suggest, a red herring here: if very early embryos are to be regarded as non-human beings by virtue of their divisibility, then so, probably, should I be."

And who was the author of this article? None other, I blush to confess, than myself. The moral, I suppose, is that the ties of identity which link us to our earlier selves - however these are to be conceived philosophically - are sufficiently tenuous for it to pay, occasionally, to brush up on one's knowledge of one's own previous thinking!

Michael Lockwood, MA, DPhil (Oxon), is University Lecturer in Philosophy (Continuing Education) and a Fellow of Green College, University of Oxford.

\section{References and notes}

1 Locke defines a "person" as "a thinking intelligent being, that has reason and reflection, and can consider itself as itself, the same thinking being, in different times and places". Locke J. Essay concerning human understanding (1690), II.xxvii.9. This has the unfortunate effect of ruling out, for example, newborn 
babies and, at the other end of life, adults suffering from advanced senile dementia. It seems to me that the term "person", as ordinarily used, is applicable at least from the time when there is a dawning of sentience within the fetus, and that the continuity of psychological development, between the late fetus and the resulting adult, underpinned as it is by a structural continuity within the relevant part or aspect of the brain, permits us to think of the same person persisting throughout. Memory is doubtless one aspect of such continuity; but Locke seems to me mistaken in presenting it, as he does (Essay concerning human understanding, II.xxvii.10), as the criterion of personal identity.

2 I develop these views in detail in my Warnock versus
Powell (and Harradine): when does potentiality coun? Bioethics 1988; 2: 187-213.

3 Emery AEH. Elements of medical genetics [6th ed局. Edinburgh, London, Melbourne and New Yorke Churchill Livingstone, 1983: 85.

4 Parfit D. Reasons and persons. Oxford: Clarendon Press 1984: part III.

5 Sperry RW. Hemisphere deconnection and unity in coro scious awareness. American Psychologist 1968; 13: 723-3

6 I discuss this at length in my Mind, brain and th quantum. Oxford: Blackwell, 1989: ch. 6.

7 Lockwood M. The Warnock Report: a philosophicád appraisal. In: Lockwood M, ed. Moral dilemmas $\overrightarrow{i 0}$ modern medicine. Oxford: Oxford University Press, 198 161-2.

\section{News and notes}

\section{Ethics and Palliative Care}

An advanced European Bioethics Seminar, Ethics and Palliative Care, will take place from April 3-5, 1997, in Nijmegen, the Netherlands. It is plausible to expect that the demand for and attention to palliative care will increase. Accordingly the International Program in Bioethics Education and Research has developed a new in-depth seminar on ethics and palliative care. Specialists from different countries will focus on The Evolution of Palliative Care, Ethical Issues in Pain
Management, The Limits of Palliative Care: Futility of Medical Treatment, Palliative Care and Euthanasia, etc. All lectures and plenary sessions will be held in English. For more information please contact: Dr B Gordijn, Catholic University of Nijmegen, 232 Dept of Ethics, Philosophy and History of Medicine, PO Box 9101, 6500 HB Nijmegen, the Netherlands. Tel: [31 $\begin{array}{llll}\text { (0)24-3615320 Fax: [31] (0)24-3540254 } & \end{array}$ E-mail: b.gordijn@efg.kun.nl

\section{News and notes}

\section{The Economics of Mental Disorders, Alcohol and Drug Addiction}

The Fourth Workshop on Costs and Assessments in Psychiatry, entitled The Economics of Mental Disorders, Alcohol and Drug Addiction, will be held in Venice from March 14-17 1997.

The workshops aim to facilitate the integration of the research performed by different disciplines to evaluate the mental health field from different perspectives (psychiatry, economics, public health and sociology).

The workshops are organised by the Association for Research into Costs and Assessments in Psychiatry, (ARCAP).

For further information please contact: Organising secretariat, ARCAP, Via Daniele Crespi 7, 20123 Milano, Italy. Tel/fax: 39-2-5810 6901.

\section{News and notes}

\section{A Time to Die}

A conference entitled A Time to Die? Ethical, Legal and Clinical Perspectives will be held at St Thomas's Hospital, Lambeth Palace Road, London SE1 on the 7th of May 1997.

The conference is being organised by the Centre for Bioethics and Public Policy, London.
For further information or registration forms contact: Graham Stanford, Centre for Bioethics and Public Policy (CBPP), 58 Hanover Gardens, London SE11 5TN. Tel/fax: 0171-587 0595; E-mail: 100524.1567@compuserve.com 